\title{
ÉRTELMEZHETŐ-E A LOJALITÁS A B2B PIACOKON?
}

A fogyasztói lojalitás elméleti és empirikus vizsgálata már több mint két évtizede népszerú a nemzetközi és hazai szakirodalomban. Hosszú ideje a vita az ügyfélhúség fontosságáról szól, és számtalan forgatókönyvet találhatunk arra vonatkozóan, hogy hogyan tartsuk meg fogyasztóinkat, és annak milyen pozitív hatásai lehetnek a B2C piacokon a szervezetek teljesítményére. Sajnos ugyanez nem mondható el a vállalatok közötti (B2B) lojalitásvizsgálatokkal kapcsolatban. Sokkal kevesebb az elméleti fejtegetés, és sokkal kevesebb az empirikus kutatás ezen a területen. A lojalitás kérdésében kétségtelenül több a hasonlóság, mint a különbség a B2B és a B2C piacokon, de mégis nagyobb figyelmet érdemelne az olyan tényezók vizsgálata a B2B piacokon, mint az érték, a kapcsolatépítés, az elkötelezettség, a bizalom, a kölcsönösség. A tanulmány egy átfogó empirikus kutatás kvalitatív vizsgálati eredményeivel kíván rávilágítani arra, hogy miként is vélekednek az egymással kapcsolatban lévố szervezetek a B2B lojalitásról.

Kulcsszavak: minôség, elégedettség, kapcsolatiság, bizalom, együttmúködés, kölcsönösség, lojalitás

A lojalitás fogalmával kapcsolatban megoszlanak a vélemények, de abban többnyire egyetértenek a szerzók, hogy a lojalitás egyfajta elkötelezettséget, húséget jelent, bár az elkötelezettséget a különbözó dimenziókban (szervezeti-fogyasztói) más megközelítésben tárgyalja a szakirodalom. Ha áttekintjük a vonatkozó szakirodalmat, a fogyasztói lojalitás definiálása egész labirintust tár elénk. Miután a tanulmány a B2B lojalitást kívánja vizsgálni, így a fogyasztói lojalitás elméleti hátterét csak érintôlegesen ismerteti. ${ }^{1}$

\section{Mi a lojalitás?}

\section{A lojalitás definiálási kísérletei}

A fogyasztói lojalitás kapcsán a szakirodalomban széles körú elemzéseket találhatunk a márkahúségre, a „,bolthüségre”, a vevôhúségre és az ismételt vásárlásokra vonatkozóan (Kandampully, 1998). A lojalitást Tellis úgy definiálja, mint az újravásárlási hajlandóságot, illetve az azonos vagy hasonló márkavásárlás relatív arányait (Tellis, 1988), Newman és Werbel szerint pedig húséges az a fogyasztó, aki úgy vásárol újra egy márkát, hogy csak azt az egyet veszi figyelembe, és nem végez más márkákhoz kapcsolódó információkeresést (Newman - Werbel, 1973). Richard L. Oliver szerint mind az elméleti, mind a gyakorlati szakemberek egyetértenek abban, hogy az elégedettség és a lojalitás közötti kapcsolat megfejthetetlen, és hogy ez a kapcsolat aszimmetrikus. Bár a lojális fogyasztók általában elégedettebbek, az elégedettség nem megy át automatikusan lojalitásba. Az elégedettség-lojalitás rejtélyének megfejtésére a szerzố tanulmányozza, hogy a fogyasztói elégedettség milyen aspektusai hatnak a lojalitásra, és a lojalitás mekkora hányada tulajdonítható az elégedettségi komponenseknek? Az elemzés következtetése, hogy az elégedettség szükséges lépés a lojalitás kialakításához, de sok más folyamat is kell a lojális vevốkör megszerzéséhez (Oliver, 1999: 33. p.). A kérdés úgy merül fel, hogy vajon miért van, hogy az elhagyási arány az elégedett vevóknél akár $90 \%$ is lehet? A válasz attól függ, hogy az elégedettség mekkora szerepet játszik a lojalitásban, az elégedettséghez köthetô faktoroknak milyen a hatása, illetve milyen a közöttük lévő kapcsolat. Az biztos, hogy az elégedettség és a lojalitás kibogozhatatlanul összefügg, és ez a kapcsolat aszimmetrikus. Noha a lojális fogyasztók többsége elégedett, az adatok tanúsága szerint az elégedettség megbízhatatlan előrejelzője a lojalitásnak. A releváns források szerint sem egyértelmú az elégedettség-lojalitás kapcsolat (Veres, 2008). 
Az újabb kutatások arra hívják fel a figyelmet, hogy a lojalitás és elkötelezettség sem szinonim fogalmak. Pritzhard és szerzôtársai (Pritzhard et al., 1999) a fogyasztói lojalitás és elkötelezettség közötti különbségeket hangsúlyozzák, és a márkahúség esetében próbálják elemezni a kapcsolatot a két tényező között. A szerzók szerint a lojális attitúd lojális magatartáshoz vezet, és a lojalitást a márka-újravásárlásokkal mérik. Az elkötelezettség azonban megítélésük szerint ennél sokkal több: erôs vágy a folyamatos kapcsolatra, a fogyasztók azonosulása a szervezeti célokkal és értékekkel. A tárgyiasult termékek és szolgáltatások iránti lojalitást vizsgálva Edvardsson és társai felhívják a figyelmet arra, hogy különbség van „kiérdemelt” és „,vásárolt” lojalitás között. A „kiérdemelt” lojalitást a jó minőséggel, a kedvező fogyasztói értékeléssel lehet elérni, amikor a fogyasztó azért tér vissza a termékhez/szolgáltatáshoz, mert azzal elégedett, a „vásárolt” lojalitás azonban valamilyen kedvezmény (kupon, árcsökkentés) felkínálásán alapul, amely rövid távú újravásárlást eredményez csak (Edvardsson et al., 2000). Hofmeister-Tóth és társai a lojalitás és a vevőmegtartás árnyaltabb értelmezésére hívják fel a figyelmet: szerintük a fogyasztói hưség, a lojalitás statikus, míg a vevőmegtartás dinamikus fogalom, és a vevőmegtartás alapjai visszanyúlnak a tranzakciós költségelmélethez, valamint a szociálpszichológia területéhez (Hofmeister-Tóth et al., 2003: 46. o.).

\section{A lojalitás dimenziói a B2B kapcsolatokban}

A vállalatok közötti kapcsolatokban az elkötelezettséget Meyer és Allen három komponensre bontotta (Meyer - Allen, 1991). Az elsố egy input komponens, amely azt fejezi ki, hogy a felek az egymás iránti elkötelezettség kialakulásakor bizonyos befektetéseket tesznek, amelyek csak az adott kapcsolatban hasznosíthatók, a második az attitúdre vonatkozik és a felek érzelmi elkötelezettségét jelzi, a harmadik pedig egy idóbeli dimenziót ad, amely arra vonatkozik, hogy az elkötelezettség csak abban az esetben áll fenn, ha mind a két fél hosszú távon gondolkodik. Az elkötelezettséget másfajta megközelítésből vizsgálja Geyskens és Steenkamp, akik egy kétkomponensú modellt alakítottak ki, ahol az első komponens arra vonatkozik, hogy a felek mennyire szeretnék fenntartani a kapcsolatot, a második pedig a kapcsolat ésszerúségére, amikor nem az érzelmek, hanem a józan számítás teszi szükségessé a kapcsolatot (Geyskens - Steenkamp, 1995).

Az elméleti modellek között figyelemre méltó Costabile dinamikus modellje, amely a lojalitás kialakulásának fázisait elemzi (Costabile, 2000). A szerzó megítélése szerint a korai elemzések (Wind, 1977; Jacoby - Chestnut, 1978; Wernerfelt, 1991; Keaveney,
1995) csak a lojális magatartást vizsgálták, azaz azt, hogy miért marad húséges a fogyasztó, illetve arra koncentráltak, hogy a lojális magatartásnak milyen formái lehetségesek (Dick - Basu, 1994), és nem fordítottak kellő figyelmet a lojalitás különböző formáinak kialakulási folyamatára (1. táblázat).

1. táblázat

\section{A mentális és a magatartási dimenziókon alapuló lojalitás}

\begin{tabular}{|c|c|c|c|}
\hline \multicolumn{2}{|c|}{} & \multicolumn{2}{c|}{ Az adott márka újravásárlása } \\
\cline { 3 - 4 } \multicolumn{2}{|c|}{} & Magas & Alacsony \\
\hline $\begin{array}{c}\text { Az adott } \\
\text { márkával } \\
\text { kapcsolatos } \\
\text { attitúd }\end{array}$ & Pozitív & $\begin{array}{c}\text { Kitartó } \\
\text { lojalitás }\end{array}$ & $\begin{array}{c}\text { Latens } \\
\text { lojalitás }\end{array}$ \\
\cline { 2 - 4 } & Negatív & $\begin{array}{c}\text { Hamis } \\
\text { lojalitás }\end{array}$ & Hútlenség \\
\hline
\end{tabular}

Forrás: Dick - Basu (1994)

Costabile dinamikus modellje a fogyasztó és a szervezet közötti kapcsolatot folyamatként ábrázolja, amelynek eredménye egy multidimenzionális konstrukció a fogyasztói lojalitásra. A modell mind a kapcsolatok, mind a lojalitás kialakulásának négy fázisát azonosítja, és ezekbôl eredményezteti az alábbi szakaszokat:

\section{Az elégedettség és a bizalom fázisa}

A vásárlás és a vásárlási tapasztalat eredménye lehet a fogyasztói elégedettség, ami a vásárlás megismétlődését eredményezheti, és ha az elégedettség tartós, úgy az ismételt vásárlás a bizalmat elmélyíti, és a kapcsolatot a lojalitás irányában erôsítheti (Bolton - Drew, 1991; Chang - Wildt, 1994; Morgan - Hunt, 1994).

\section{A bizalom és az újravásárlás fázisa}

A bizalmi tốke elmélyülése növeli az újravásárlás esélyét és a lojalitás kialakulását, de ha figyelembe vesszük Tuckman konfliktuselméletét (Tuckman, 1965), miszerint a konfliktusok kezelése vagy erősítheti, vagy csökkentheti a kapcsolatok elmélyülését, úgy azt mondhatjuk, hogy a bizalom kialakulása nem elégséges feltétele a lojalitásnak. A bizalomból az újravásárlási fázisba történó átmenetet kísérheti az összehasonlítás egy új folyamata, amikor viszonylagos konfliktus alakul ki a tapasztalt érték és a piacon felajánlott alternatív értékek között. A konfliktus jelentheti a kapcsolat végét, de meg is erósítheti a kapcsolatot.

\section{A mentális lojalitás fázisa}

A konfliktus pozitív megoldása azt az érzetet keltheti a fogyasztóban, hogy a szervezet képes kedvezóbb értéket nyújtani, mint a versenytársak, és hosszú távon fenn tud tartani egy állandó értéket. Ebben a szakasz- 
ban alakul ki a monadikus lojalitás, amikor a szervezettel való kapcsolat megszokássá válik. Ez a hit - ami megerósíti a fogyasztó önigazolását is abban, hogy jól választott, és érdemes a jelenlegi partner mellett kitartania - elvezet a mentális lojalitáshoz. A mentálisan lojális fogyasztó jellemzője a passzivitás, a versenytársak ajánlásai közötti keresés korlátozottsága.

\section{Az együttmúködési lojalitás fázisa}

A magatartási és mentális lojalitás a szervezet iránt elvezethet az együttmúködési fázishoz. Az együttmúködés, a kooperáció feltételezi a kölcsönösséget, a méltányosságot és a korrektséget. Ez már a diadikus lojalitás, azaz az egyenértékúség, a méltányosság észlelése a cserefolyamatban. Bár a diadikus lojalitás értelmezése hasonló a Jacoby és Chestnut (Jacoby - Chestnut, 1978) által definiált ,,igazi lojalitáshoz”, a ,kitartó lojalitáshoz" (Dick - Basu, 1994) és a ,proaktív lojalitáshoz” (Oliver, 1997), de mégis más: annyiban új, hogy mindkét fél részérôl feltételezi a kölcsönösséget, az egyenértékúség érzését kelti és a korrekt partneri kapcsolaton alapuló együttmúködést támogatja.

A kapcsolatiságot és a lojalitást ötvözve alakul ki az a multidimenzionális modell, amely a lojalitás folyamatát és a kapcsolati stádiumokat összefoglalva tipizálja a fogyasztókat (2. táblázat).
(Grönholdt et al., 2000). Vannak azonban, akik megkérdőjelezik a kapcsolat egyértelmúségét. Utóbbiak felhívják a figyelmet arra, hogy az elégedettség nem elég, és a legelégedettebb fogyasztók nem válnak szükségszerúen lojálissá, valamint hogy nagyon sok elégedett fogyasztó elhagyja a szervezetet (Jones - Sasser, 1995; Reicheld - Sasser, 1990; Reicheld, 1996; Oliver, 1999; Neal, 1999).

Az elmúlt évtizedben lezajlott néhány hazai empirikus kutatás eredményei is azt jelzik, hogy az elégedettség hatása a lojalitásra nem minden esetben meghatározó, és feltételezik, hogy a lojalitás dimenziói ágazat-, termék- és szolgáltatásspecifikusak (Kenesei, 1998; Hetesi, 2001; Veres, 2007; Ercsey, 2008).

A vállalatok közötti lojalitás dimenzióinak mérésére kevesebb az empirikus kutatás, és e körben a fogyasztói lojalitástól eltérố dimenziókat is találunk. Amikor a Guerilla Consulting ügyfelei körében a lojalitással kapcsolatban kutatást végeztek, a szakmai szolgáltatók 50\%-a úgy válaszolt, hogy a húséggel kapcsolatban közönyös, és habozás nélkül váltana. A kutatásból kiderül, hogy a lojalitás szorosan kötődik az ügyfél megítéléséhez, és a szervezeteknek törekedniük kell arra, hogy kielégítsék, illetve meghaladják a vevői elvárásokat ahhoz, hogy a lojalitás kialakuljon (Meugniot, 2008).

2. táblázat

\section{A kapcsolatok lehetséges tipológiája}

\begin{tabular}{|c|c|c|c|}
\hline \multirow{4}{*}{$\begin{array}{c}\text { Monadikus } \\
\text { érték }\end{array}$} & Negatív megkülönböztetés & $\begin{array}{c}\text { Mentálisan hazardírozó lojalitás } \\
\text { (instabil mentális lojalitás, opportunizmusra } \\
\text { való hajlam, alternatívák keresése) }\end{array}$ & $\begin{array}{c}\text { Lojális kapcsolat } \\
\text { (stabilitás, együttmúködés, a } \\
\text { partnerségre való hajlam) }\end{array}$ \\
\cline { 2 - 4 } & Pozitív megkülönböztetés & $\begin{array}{c}\text { Korlátozott vagy tehetetlen kapcsolat } \\
\text { (magatartási lojalitás, az alternatívák aktív } \\
\text { keresése, váltási költségek figyelése) }\end{array}$ & $\begin{array}{c}\text { Reményteli kapcsolat } \\
\text { (magatartási lojalitás, } \\
\text { időkorlát, az alternatívák } \\
\text { szelektív keresése) }\end{array}$ \\
\cline { 2 - 4 } & \multicolumn{2}{|c|}{ Inkorrektség } & Korrektség \\
\cline { 2 - 4 } & \multicolumn{2}{|c|}{ Diadikus érték (egyenértékúség) } \\
\hline
\end{tabular}

Forrás: Costabile (2000)

\section{Empirikus kutatási eredmények}

Számos empirikus felmérés igazolja, hogy a fogyasztói elégedettség és a lojalitás között szignifikáns kapcsolat mutatható ki (Fredericks et al., 1995; Dickey, 1998; Gitomer, 1998; Martensen et al., 2000; Parasuraman Grewal, 2000). Az ECSI-modellt egy ,pilot study”-ban alkalmazták, melyben 12 európai ország vett részt és közel 55000 interjú készült. Az eredmények alapján a fogyasztói elégedettség jelentősen befolyásolja a lojalitást. A kapcsolat erós magas magyarázó eróvel bírt a 30 vállalatnál, valamint a 6 iparágban, a regresszióanalízis azt jelezte, hogy a kapcsolat erősen szignifikáns

\section{A lojalitási dimenziók empirikus kutatása egy hazai nagyvállalatnál}

A fentiekben ismertetett modellek és empirikus kutatási eredmények tesztelésére és a lojalitást befolyásoló tényezók meghatározására a hazai B2B piacon kvalitatív és kvantitatív módszerekkel kombinált kutatást végeztünk. A vizsgálat célja egy olyan lojalitásmodell kialakítása volt, amely a lojalitásra ható tényezóket inputként fogja fel, és az azok javításáért tett erőfeszítések hozamát a húség outputjaként értelmezi. Longitudinális vizsgálatok hiányában a modell természetesen csak hipotetikus lehet, de talán iránytúként szolgálhat további hazai kutatási modellek megalkotásához. 


\section{Kutatási koncepció}

Kutatási modellünk központi eleme a lojalitás, amelyet mi az alábbiakban definiáltunk:

„Lojális az a partner, aki elkötelezett a cég iránt, kisebb elégedetlenség és a versenytársak által felkínált kisebb árengedmények estén nem hagyja el beszállitóját, és azt ajánlja más vevóknek is, valamint hajlandó az együttmúködésre."

Kutatási modellünk kiindulópontját azok az elméleti megközelítések és empirikus vizsgálati eredmények jelentették, amelyek felhívták a figyelmet arra, hogy a fogyasztói lojalitás mérési dimenziói nem standardizálhatók, a dimenziók és azok meghatározó ereje függ a vizsgált ágazattól, terméktól, szolgáltatástól (Oliver, 1997; Edvardsson et al., 2000; Costabile, 2000; Kenesei, 1998; Hetesi, 2001). További támpontul szolgáltak a B2B lojalitás speciális szakirodalmi megközelítései, és a fogyasztói lojalitástól eltéró tényezók szerepeltetése az elméleti és empirikus vizsgálati modellekben (Geyskens - Steenkamp, 1995; Meyer - Allen, 1991; Elliott - Glynn, 2000).

Az általunk definiált lojalitás dimenzióit a lojalitás és a minőség-elégedettség-lojalitás-jövedelmezőség lánc értelmezésén, a kapcsolatiság, az elégedetlenség ellenére való ragaszkodás és a bizalom dimenzióin keresztül mértük.

A differenciált elméleti megközelítéseket és a standardizálhatóság korlátjait figyelembe véve egy hazai nagyvállalat esetében vizsgáltuk, hogy:

- miként értelmezi a szállító, illetve hogyan definiálják a partnerek a lojalitást,

- hogyan értelmezik a minôség-elégedettséglojalitás lánc kapcsolatát a vizsgált szervezet partnerei,

- milyen szerepe van a kapcsolatiságnak a lojalitásban,

- mi a szerepe a bizalomnak a lojalitásban,

- húséges lehet-e, és ha igen, miért az elégedetlen partner.

A modellben az elméleti megközelítések alapján nem szerepel új dimenzió, de a fogyasztói lojalitás empirikus felméréseihez képest újszerúnek tekinthetô a bizalmi tényezó beemelése az empirikus felmérésbe, a szervezeti lojalitáskutatásokhoz képest pedig az elégedetlen partnerek lojalitási motivációinak vizsgálata jelent új elemet.

Kiinduló modellünk a 1. ábrán található tényezóket tartja fontosnak a B2B lojalitás kialakulásában.

\section{A lojalitás input-output modellje}

INPUT TÉNYEZŐK

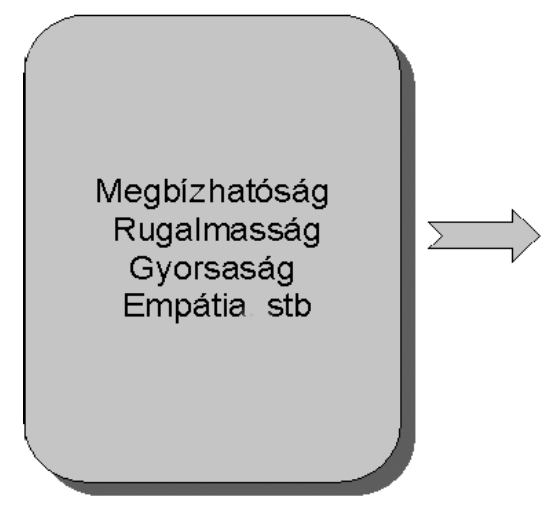

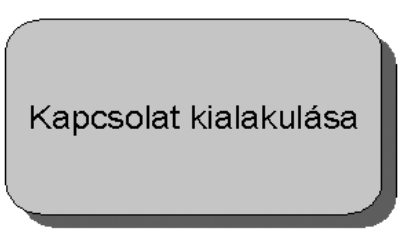

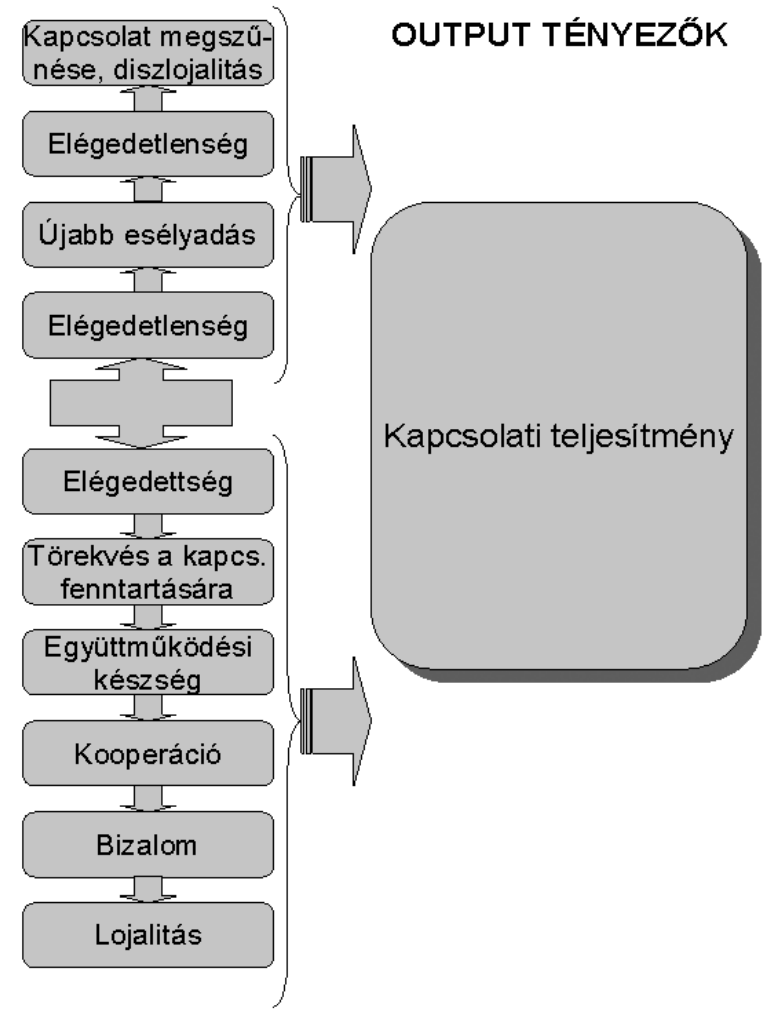


A kapcsolati teljesítmény faktorainak kifejtésére a tanulmány keretei között nincs mód, de korábbi cikkünkben (Hetesi - Vilmányi, 2009) ezeket részletesen ismertettük.

\section{A kutatás lebonyolitása}

Az empirikus kutatást egy hazai nagyvállalat partneri körében végeztük. A kvalitatív vizsgálat során elsőként fókuszcsoportos megkérdezés történt a cég kompetens személyeinek részvételével (marketingegység vezetôje, értékesítési egység vezetôje, ügyfélszolgálati vezetô, humánerôforrás-egység vezetôje, kulcspartnerekkel kapcsolatot tartó személyek, kisbeszerzókkel kapcsolatot tartó személyek) a lojalitás megítéléséról, majd 20 partnercég kapcsolattartójával mélyinterjút készítettünk. Az interjúban résztvevő́k kiválasztása céglistáról történt, ahol figyelembe vettük a területi elhelyezkedést. A fókuszcsoportos megkérdezés és az interjúk kérdései az összehasonlíthatóság érdekében hasonlóak voltak.

A kvantitatív felmérés kérdéseit az elôzetes kvalitatív kutatás következtetéseire építettük, és ennek megfelelően finomítottuk a mérési dimenziókat. A kérdőíves vizsgálat 105 partnercégre terjedt ki, ahol a kiválasztásnál figyelembe vettük a cégek telephelyét, a megkérdezés pedig telefonos interjúkkal történt. Jelen tanulmányban csak a kvalitatív kutatás eredményeit ismertetjük, a kvantitatív kutatás elemzését korábbi cikkünkben bemutattuk (Hetesi, 2007).

\section{A kvalitatív kutatás eredményei}

A következókben azokat a kutatási eredményeket mutatjuk be, amelyek a modell használhatóságát igazolják, illetve cáfolják.

\section{Ki a hüséges partner?}

A kvalitatív kutatások eredményei alapján érdekesnek tekinthető az az eredmény, miszerint a beszállító cég munkatársai szkeptikusak a lojalitással szemben: szerintük a hứség divatjamúlt kategória, és a szállító megválasztásánál az ár szerepe a döntő. ,....ahogy változik most a világ, úgy a lojalitás minden területen, nemcsak a kereskedelemben, hanem a világon minden területen visszaszorul, így azt gondolom, hogy ezt újra kell értelmezni. Ezt a lojalitást valahogy át kellene fogalmazni, mást kellene kitalálni, mert ez egy elavult kategória, sajnos az üzleti életben és a mindennapi életben is."

Ezzel szemben a vevói körben fontos szerepe van az elkötelezettségnek. „Hüséges partner? Aki nem hajlandó pillanatnyi és ideig-óráig fennálló, akár bizonyos szempontból kedvezóbb, de bizonytalanabb üzleti lehe- tôségekért felrúgni, felborítani olyan régi, normálisan múködö üzleti kapcsolatokat, ahol háttér van, aminek perspektívája van, múltja, jelene és jövóje is van."

A partnerek általános felfogását a húségrốl a fenti idézet talán kellóképpen demonstrálja, ám néhány árnyalatnyi véleménykülönbség felvillantását mégis fontosnak tartjuk. Az interjúalanyok egy része a húséget a kapcsolatiságban határozta meg, és kiemelkedő szerepet tulajdonított az általános elégedettségnek, a szimpátiának, a megszokottságnak, a stabilitásnak és az együttmúködésnek (pl. a terméktervezésben).

„A hüségünk abban rejlik, hogy megszoktuk a céget, megbízunk bennük, a megszokás dominál.” „Azért maradunk, mert elégedettek vagyunk a beszállítóval, nem módosítanánk, mert ami bevált, és ami jól múködik, az maradjon.” „Tulajdonképpen az a hüség, ha egy hoszszabb idôszakon keresztül tudunk együtt dolgozni, illetve gyakorlatilag, ha Ố az én felmerüló igényeimet folyamatosan megfeleló módon ki tudja elégiteni, akkor én sem fogok arra kényszerülni, hogy az én igényeim kielégitése érdekében más szállitóhoz forduljak. Hogyha ezt meg tudjuk oldani, akkor tudunk hosszan egymással dolgozni. És akkor az üzleti kapcsolat során hüségesek leszünk egymáshoz.” „Hüséges az a partner, aki nem vált azonnal csak az ár miatt beszállítót."

A fenti tényezók hasonlítanak a Costabile (Costabile, 2000) által konstruált dinamikus modell egyes fázisaihoz: az elégedettség és a szimpátia bizalmat eredményez, a megszokottság a diadikus lojalitást jelenítheti meg, amely egyfajta mentális kötôdést eredményez, a stabilitás és az együttmúködési hajlandóság pedig a méltányosságon, az egyenértékúség érzékelésén keresztül elvezet a diadikus lojalitásig.

Az interjúalanyok másik része sokkal bonyolultabbnak tartja a húség kérdését, és esetenként lojalitás-definiálási kísérletekkel is találkozhatunk. „Manapság nem divat ezt mondani, és igazán még az se nagyon érzékelódik, hogy a két cég kapcsolatában a lokálpatriotizmus is mindent elsöpró fontosságú lenne. Alapvetóen végül is azért emberi kérdés ez, mögötte azért mindig vannak emberi kapcsolatok és emberi kérdések. Sokkal könnyebb olyan légkörben dolgozni, ha tudom, hogy engem nem fognak átverni. Ha tudom, hogy megállapodást kötöttem, és amit ígértek az teljesülni fog. Ezt különbözó cégek, emberek máshogy értékelik, én személy szerint ezt nagyon nagyra értékelem. Azokkal a cégekkel, amelyekkel évtizedek óta együtt dolgozom, igyekszem emberi szempontból is tartani a kapcsolatot, jó emberi nexust kialakítani velük, és azt lehetóség szerint fenntartani."

Egy kisebb csoportot alkotnak, de meghatározó véleményt fogalmaztak meg azok a partnerek, akik a hú- 
séget nem kívánták definiálni és értelmezni, egyszerúen csak a racionalitás talaján maradva értékelték a céglojalitást, azaz a beszállító melletti kitartást kényszerként kezelik. „Azért maradunk, mert szerzôdés köt rá bennünket.” „Azért maradunk, mert a cég monopolhelyzetben van, Magyarországon kevesen gyártanak ilyen terméket. Ha több cég foglalkozna vele, nem hiszem, hogy hüségesek maradnánk. Ök diktálják az árakat, azt mondom, hogy ez egy kényszerhelyzet.” „Budapesten monopolhelyzetben van a cég, nincs lehetóség más céget kipróbálni.” „Megjegyzem, sokan jelezték, hogy elhagyták a céget és átmentek a szlovákokhoz."

\section{A partnerek lojalitását meghatározó dimenziók}

Mint azt már érintettük az előzőekben, a lojalitás dimenziói a szakirodalomban is kérdésesek, és ez a tény a vizsgálat során is megerósítést nyert. A fókuszcsoportos felmérés eredményei is arról vallanak, hogy a húség mérhetôsége bonyolult, és a 20 mélyinterjú tartalomelemzése is ezt a tényt támasztja alá.

\section{A személyes kapcsolatok}

$\mathrm{Az}$ interjúalanyok többsége kiemelt jelentőséget tulajdonít a személyes kapcsolatnak, mások inkább az árakat és a minôséget tartják fontos befolyásoló tényezônek. A személyes kapcsolatok jelentőségét számos tanulmány elemzi (Gedeon - Fearne et al., 2009; Andersen - Kumar, 2006; Reid et al., 2004). „A személyes kapcsolatok, a kiszolgálás miatt vagyunk hüségesek." „Hüségesek vagyunk a határidók pontos betartása és az árak miatt.” „Nagyon sok függ a személyes kapcsolatoktól. A személyes kapcsolatok, a szimpátia, az unszimpátia kérdése ebben biztos szerepet játszik, és aztán a rugalmasság és a minóség. Ha ez a három dolog múködik, akkor húségesek vagyunk."

A hosszú ideig húséges partner elpártolásának egyik nagyon fontos okaként merült fel az „emberi kapcsolatok” szerepe a beszállító megválasztásában. „Sokat számíthat, ha valahol jó személyes kapcsolat van. A személyes szimpátia befolyásoló tényezó, akármennyire is tagadjuk. Az üzleti életben lehet, hogy nem kellene ilyennek létezni, de mégis létezik.” „Nézze, én úgy gondolom, hogy a mai világban, a mai rendszerekben a baráti viszonyok, kapcsolatok elég sokat jelentenek, és jön egy jó barát, egy jó ismerós, akivel közvetlenebb, barátibb a viszony, és esetleg elképzelhetó, hogy emiatt vált valaki szállítót."

A piaci verseny és az ár szervezeti hüséget befolyásoló dimenziói

A szakirodalom szerint a húség egyik fokméróje a piaci versenyhelyzet, a szervezetek kompetitív pozíci- ója. Ahol a verseny éles, ott a lojalitás gyengébb, ahol mérsékelt, ott erősebb, és „kényszerhúség” lép fel. Az interjúalanyok a piaci versenyben szinte valamennyien az ár szerepét emelték ki, azaz egyértelmúen jelezték, hogy a versenyben a kedvezóbb árat kínáló fél élvez előnyt, annak ellenére, hogy a korábbiakban a húség dimenziójaként a kapcsolatiságot és a minôséget is megjelölték. „Az ár nagyon fontos, ez teszi vonzóvá a partnert.” „Más partnert csak az ár tenne vonzóbbá.” „Jobb árak és ugyanolyan kiszolgálás.” „Az ár az elsố körben, a többi egyéb oldalt olyankor még nem ismerjük.” „Húségból nem lehet megélni. Tapossák az embert fillérért, forintért. A piaci versenyben nincs hüség, csak ár. Ha többen lennének a piacon, nem biztos, hogy ettól a cégtól vásárolnánk.” „A cégvezetés azt várja, hogy a lehetó legjobb feltételekkel vásároljak, a hüség háttérbe szorul. Talpon maradni a cél."

$\mathrm{Az}$ árak preferenciáiról fontosnak tartjuk megjegyezni, hogy a fóvárosi mélyinterjúkban kizárólag ezt a versenytényezôt említették a partnerek, míg a vidéki vevôk körében más szempontok is teret nyertek. Körükben akadtak olyan interjúalanyok is, akik az áron kívül más versenyelőnyöket is preferáltak, nevezetesen a minőséget és a határidőre való teljesítést. „A választás nemcsak ár, hanem minóség kérdése is. A jó minóség megéri az árát.” „Nagyon fontos, hogy jó árak legyenek, de az ár nem minden, a minóség is nagyon fontos, és a határidôre történó teljesítés.” „Az ár egy borzasztóan fontos dolog, különösen a mai világban, ...ennél csak egy fontosabb dolog van, a minóség."

A szervezetek elégedettsége és a szállitói lojalitás öszszefüggése

A szakirodalom szerint az elégedettség vezet a húséghez, de elófordul, hogy az elégedetlen vásárló is lojális marad. A cég vidéki partnerei nagyon árnyaltan közelítették meg azt a kérdést, hogy vajon elégedetlenség esetén is maradnak-e a jelenlegi beszállítónál, míg a budapesti interjúalanyok szinte valamennyien határozott nemmel válaszoltak. A vidékiek az elégedetlenség mértékétôl tették függôvé a döntést, és úgy gondolják, hogy hiba nélkül nem lehet dolgozni: „Aki úgy gondolja, hogy egy ipari terméket le lehet hibátlanul gyártani, az téved. Én még nem láttam olyan ipari terméket, amelyben ne lehetne hibát találni." „A kérdés az, hogy a hiba mértéke milyen és mennyi”, ezért kisebb vétségeket elnéznek, és mintegy adnak még egy esélyt a beszállítónak: „Elófordulnak hibák, de velünk is elófordulhatnak. Egy-egy idószaki rossz teljesítés miatt nem fogunk váltani. Nálunk is voltak rossz idók, és a szállítóink mégis kitartottak mellettünk." Az elégedetlenség érzését csökkentheti a tartós, hosszú távú 
kapcsolatból származó sok pozitív tapasztalat is: „, Van két serpenyó: az egyikbe belepakolom azt, hogy mik a pozitívumai az eddigi többéves kapcsolatnak...na, most ez lehúzza a mérleg nyelvét elég tisztességesen. A másikba jönnek a problémák, és akkor lehet mérlegelni. Persze az nem mindegy, hogy milyen súlyú a hiba”, ám a partnerek szerint tartós elégedetlenség esetén csak akkor marad a vevő, ha nincs más választása. „Az nem lehet, hogy folyamatos rossz teljesítés esetén marad a vevó. Itt gyártásról van szó, ezt nem lehet megengedni. Ha a hibákat nem orvosolják, akkor elmegy a vevó, és nem is kell keresgélnie új beszállitót, mert mindig vannak ajánlatok."

A hosszú ideje húséges partnerek elpártolásának alapvető okaként a budapesti partnerek - egy kivételével - valamennyien az árat, a költségcsökkentési kényszert, az anyagi érdekeltséget említették: „Az ár az elsódleges, az ár nagyon meghatározó a mai világban, csak az ár miatt..." Egy partner azonban a rugalmasságot és a reagálási készséget jelölte meg a beszállítóváltás lehetséges okaként: „Gyorsabban reagálnak a cég versenytársai. Kisebb mennyiséget is legyártanak, egyéni minóségi igényeket is ki tudnak elégíteni."

Mások az ár mellett a minőséget és a szállítási teljesítés hiányosságait említették: „Az ár, a minôség, a jobb termék.” „A fö okok, ha a minôség romlik, az ár növekszik, vagy pontatlanok a szállítások”, de arra is találtunk példát, amikor indoklás nélkül magasabb szinten születik döntés a partnerváltásról: „Olyan is lehet - amivel én nem értek egyet -, hogy más döntés születik magasabb szinten. Volt már rá példa. A mi életünkben is volt néhány évvel ezelótt, hogy azt mondta az anyagellátó központ, hogy márpedig innen kell. Onnan kellett venni. Hiába tiltakoztunk, hogy ez így nem lesz jó, ezt mi nem így látjuk, attól még onnan kellett venni, három-négy hónap múlva bedöglött az egész. Megoldotta az élet. És akkor visszamentünk a régihez, visszarendezódött minden oda, ahonnan elindult."

A vevóknek a céggel szemben megnyilvánuló lojalitása

A húség általános dimenzióin túl arra is kíváncsiak voltunk, hogy a beszállító partnerei milyen speciális cégjellemzóket említenek meg a hưség okaként. Amikor a partnereket arra kértük, hogy maguk fogalmazzák meg mi is a lojalitásuk alapja, a következóket említették:

A húség alapja

- a megbízhatóság („1-2\%-ért nem megyünk máshoz, nálunk vállalati filozófia a hüség, pl. a megalakulás óta egy banknál vagyunk. A megbízhatóság az nagyon fontos! A mi politikánk, hogy inkább drága, de megbízható legyen. Nem megszokásból, megbízhatóságból vagyunk hüek.”),
- a bizalom (A lojalitásunk kölcsönös, nyitottságot is jelent, persze leszámítva az üzleti titkot. Fontos a bizalom, mi megbízunk egymásban, megosztjuk az információt."),

- a minôség („A cég által gyártott termékek minósége jó.” „Mi a beszállítóval meg vagyunk elégedve, mármint az anyagminóséggel.” „Jó a minósége, mármint az alapanyag minôsége."),

- a pontosság („Húségesek vagyunk a szerzódéses feltételek, a szállítási határidók pontos betartása miatt.” „Pontosan szállítanak, a szállítási határidóket betartják, a mi elvárásainknak megfelelnek.”),

- a jó személyes kapcsolat („A személyes kapcsolatok, a kiszolgálás miatt vagyunk hüek. Ök is kompenzálják a régi megrendelóket, kedvezményekkel az alapárak tekintetében, a kiszolgálással.” „Nekem személy szerint felértékelt a jó kapcsolat.” „Nagyon sok függ a személyes kapcsolatoktól...”),

- a korrekt magatartás (Húségesek vagyunk, 10 éve együtt dolgozunk, mert jó, kiegyensúlyozott a kapcsolat. Hogy a piacon tudjunk maradni, kell a közös teherviselés, a beszállítónak is van felelóssége.” „Ha az ember háta mögött megpróbálnak valami olyasmit tenni, amiról nemhogy nem értesítenek, hanem eltitkolják, ez vezethet oda, hogy elmegyünk. Nagyon könnyú ebben a szakmában eljátszani a becsületet, de hát olyan partnernél ez. fel sem merül, aki nem erre játszik. A mi beszállitónk nem ilyen."),

- a rugalmasság (,Egy olyan multicégnél, amilyenek mi vagyunk, a rugalmasság és az ár a kérdés." „Mi tejipari cég vagyunk, alapellátást biztosítunk, itt nem lehet, hogy bejönnek a megrendelések, és zökkenókkel teljesítünk. Ezért nagyon fontos a rugalmasság, és mi csak nagyon óvatosan váltunk. A cég megérti a problémáinkat, mi is az övéket." „Azért tartunk ki a beszállítónál, mert rugalmasak, minóségiek a termékeik, a szállítási határidót betartják."), és

- a segítoókészség („Azért vagyunk hüségesek, mert nemcsak az áru minóségével, hanem az ahhoz nyújtott szolgáltatásokkal is próbálnak a vevóvel töródni, foglalkozni. Közösen oldjuk meg a problémákat.”).

A beszállítóval szembeni húséget negatívan befolyásoló tényezók

A korábbiakban már említett verseny által diktált feltételeknek való megfelelés gyengíti a partnerek húségét, és az esetleges hiányosságok rendszeres ismétlődése gondolkodóba ejti a vevóket. 
Kétségtelen, hogy a versenyben az ár tünik a legfontosabb partnerváltást befolyásoló tényezónek („A cégvezetés azt várja, hogy a lehetó legjobb feltételekkel vásároljak. A hüség háttérbe szorul. Talpon maradni a cél. Nálunk vadkapitalizmus van, már 1-2\%-ért változtatnak, nem úgy, mint az osztrákok és németek, ók enynyiért nem hagyják el egymást."), de más szempontok is szerepet játszhatnak a beszállítótól való elpártolásban. A cég partnereinek többsége a lojalitás mellett voksolt, de találkoztunk a húséget illetôen bizonytalan vevôkkel is.

Néhány partner pl. a kényszerhúséget emelte ki (,„Azért maradunk hüségesek, mert a cég monopolhelyzetben van. Ha több cég foglalkozna ezzel a tevékenységgel, nem hiszem, hogy hüségesek maradnánk. Ók diktálják az árakat. Azt mondom, ez egy kényszerhelyzet. De ezzel a termékkel kapcsolatban nincs lehetóség igazán változtatásra. A tólük kivált egyik cég is ugyanazokon az árakon dolgozik, én azt is elképzelhetónek tartom, hogy megegyeztek."), mások arra figyelmeztettek, hogy hipermarketekbe való bejutás olyan gazdaságossági feltételeket támaszt, amit nehéz teljesíteni (, $A$ céggel kapcsolatban nem kerül szóba a partnerváltás. De a hipermarketek csavarják a beszállitókat. Pl. két cég azt mondja nekem, hogy 5,- Ft is számít. Ha mindenütt spórol 2\%-ot, akkor befér a hipermarketekbe.") és megint mások a kíméletlen versenyt jelölték meg a húséget gátló tényezốként. (,A piaci versenyben nincs hüség. Ha többen lennének a piacon, nem biztos, hogy ettól a beszállítótól vásárolnánk.")

\section{A partnerek megtartására irányuló eszközök és a} vásárlói hüség kapcsolata

$\mathrm{Az}$ interjúalanyok többsége tudatában van annak, hogy a cég komoly erófeszítéseket tesz a partnerek megtartása érdekében, és ezeket az erőfeszítéseket pozitívan értékelik. A legtöbben az árakkal és a fizetési és szállítási határidókkel kapcsolatos különleges bánásmódot említették mint vevőmegtartási eszközt. (, $A z$ árengedmény az alapárhoz képest 8\% körül mozog”; vannak cégre szabott árak, és 60 napos fizetési határidô." „Tudom, hogy vannak dolgok, amit mi kapunk, és biztosan vannak olyan kedvezmények, amiket más kap, mi pedig nem.” „Az egyéni kedvezményeket a szállitási határidóknél már éreztük, hogy nagyon gyorsak, ha kellett valami, azt megkaptuk. Ez nagyon jólesett. Úgy éreztük, hogy ez egy felénk való gesztus, és idónként ez nekünk nagyon sokat számít...”)

Szinte valamennyi interjúalany kitért a beszállító által szervezett rendezvényekre, ezek megítélése azonban kissé eklektikus. Egyesek nagyon hasznosnak, jó hangulatúnak és a kapcsolatot erősítő eszköznek tekintik a közös találkozókat. („,Tavaly egy hajókiránduláson voltunk, elmentünk oda és vissza jó hangulatban. Egymással is találkoznak a megrendelók, más céges kollégákkal, ez hatásos. Sớt grafikai stúdiókat is meghívnak, ezek nagyon hasznosak." Vannak vevótalálkozók... ott egy kicsit úgy érzi az ember, hogy fontos, pedig valamilyen szinten tudjuk azt mi, hogy melyik polcon van a helyünk.”) Mások szerint szelektálják a meghívottakat (,Egyéni megkülönböztetés nincs, illetve negatív. Mi nagyvevók vagyunk, és nem hívnak meg a rendezvényekre. Nem tudom, hogy ez csak figyelmetlenség-e, de más partnerektól tudom, hogy vannak ilyen találko$z o ́ k$."), és olyan partner is akadt, aki nem sok értelmét látja a rendezvényeknek. („A beszállitó rendszeresen egy évben kétszer - de jellemzó, ezt is pár héttel ezelótt tudtam meg - szervez a partnereinek ilyen vevótalálkozót, ami mindig össze van kötve azért valamilyen szakmai dologgal. Itt vagyunk mi, talán kettón, ha részt vettünk. Nagyon színvonalas dolgokat szoktak szervezni, de nem hiszem, hogy ezzel azért meg lehet fogni a partnert. Lehet, hogy valakinek ez számít, hogy minden évben kétszer elmegy, hogy jót egyen meg igyon - mert vannak ilyen típusú emberek, akik elmennek mindenre - mi nem szoktunk elmenni mindenre.")

\section{A beszállító ajánlása másoknak}

A nemzetközileg elfogadott modellek a lojalitás egyik legfontosabb mérési dimenziójának tekintik a másoknak való ajánlás mértékét. A beszállítói fókuszcsoporton elhangzott, hogy ,..szerintem bennünket a partnerek nem ajánlanak másoknak, azt hiszem, ez ma nem divat", ezzel szemben a beszállító esetében az interjúalanyok szinte valamennyien lelkesen nyilatkoztak e kérdésről, és aláhúzták az e téren végzett „,szájreklámnak" nevezhetố kommunikációs tevékenységük hatékonyságát, azaz a partnerek többsége jó szívvel ajánlotta és ajánlja is a beszállítót más partnereknek. (, Ismerem óket, voltam a gyárban is, nyugodtan merem ajánlani óket.” „Igen, szoktam is.” „Maximálisan. Mindenképpen csak nagyfelhasználónak.”)

A vevók helyi kapcsolattartóinak és a központi menedzsment érdekellentétének hatása a szervezeti lojalitásra

A húséget a partnerek cég által megadott kapcsolattartó személyei véleményezték az interjúkban, a tényleges beszállító melletti döntést azonban gyakran nem ók, hanem a felsố menedzsment hozza. Ez a tény sok esetben jelentősen befolyásolhatja a beszállítók közötti választást. A partnerek véleménye a kérdésben nagyon szóródik, az önálló, független döntésektól a teljes kiszolgáltatottságig minden helyzettel találkozhatunk. Tendenciaként megállapítható, hogy minél kisebb egy cég, annál kevesebb a lehetôség a felülrôl jövő befolyá- 
solásokra. („Mi 100\%-ban privát cég vagyunk, ketten vagyunk tulajdonosok, mi határozzuk meg a beszállítókat.” „A cégvezetóség nem foglalkozik azzal, kitól rendelek, teljes szabadságom van. Mi hatfós cég vagyunk.")

A multinacionális szervezeteknél azonban - és különösen azoknál a partnereknél, akiknél a közelmúltban tulajdonosváltás történt - csökkent a döntési szabadságfok. (,Nekünk már kevés befolyásunk van a szállitó megválasztásában. Valamilyen befolyásunk lehet, de mi a beszállitóban nem dönthetünk. Most lehet, hogy az európai beszerzési vezetó azt fogja mondani, hogy gyerekek, Ausztriából fogjátok kapni az árut, onnan kell venni." „Ami megmaradt, az a véleményezés, illetve a tapasztalatok jelzése. Nem tudjuk azt sem, hogy milyen alapokon választ a központ. Én korábban belefolytam, de most ez a helyzet van.” „Teljes mértékben a vezetöség dönt, mióta új tulajdonos van, nincs semmi jogkörünk.”)

Több partner is jelezte, hogy a menedzsment akkor is dönthet másként, ha neki nagyon jó a kapcsolata a beszállítóval, és gyakran fogalmuk sincs arról, hogy milyen erók játszanak szerepet a döntésekben.

\section{Összegzés}

Kutatásunk eredményeként megállapítható, hogy a szervezeti lojalitás kapcsán a B2C lojalitásdimenziók másként értelmezendôk, és a húség megítélésében új sajátos tényezókkel is találkozhatunk. Az olyan elemek, mint az elkötelezettség, korrektség, egyenértékúség, függőség, kooperáció egészen más kontextusba helyezik a B2B lojalitást, és e tényezók mérése új távlatokat nyithat meg a szervezeti húség elméleti megközelítésében. Bár nagyon sok a hasonlóság a húséget eredményező elemek között a két piacon, az eltéró piacszerkezeti és kapcsolati (függőségi) viszonyok következtében ezek az elemek más megvilágításba kerülnek, és új értelmezéseket kívánó tényezók és megjelennek a B2B lojalitásban.

Fontos kiemelnünk, hogy a kvalitatív kutatás eredményei alapján másként vélekednek a húségról a beszállító, illetve a partnerek kompetens szereplői, és eltéróek a vélemények a másoknak való ajánlásokról is. Ezek az aszimmetrikus vélekedések is további vizsgálatokat igényelnek.

Hasznos információkat kaptunk arra vonatkozóan, hogy miért marad húséges az elégedetlen partner, és milyen lépések vezethetnek oda, hogy diszlojális lesz a partner. A kutatás felhívta a figyelmet arra is, hogy a hatalmi függőség esetében egy új, cizelláltabb modellbe célszerú beépíteni azokat a döntési mechanizmusokat, amelyek a konkrét kapcsolatot befolyásolják. Bizonytalan ugyanis az, hogy milyen szinten és miért, milyen okból marad meg egy kapcsolat, illetve miért szúnik meg.

Megerősítést nyert, hogy a személyes kapcsolatok szerepe az üzleti szférában igen jelentôs, és bár az árérzékenység nagyon fontos dimenzió a húségben, úgy túnik, hogy az olyan tényezók, mint a kapcsolatiság, a bizalom, az elkötelezettség és az együttmúködésre való hajlam egyre jelentôsebbé válnak.

Az empirikus kutatás a válság kirobbanása előtt történt: nagy kérdés az is, hogy a válság hatására hogyan alakul majd a lojalitás felfogása a szervezeteknél, ezért úgy gondoljuk, hogy kiinduló modellünket a jövőben árnyalni kell, és az árnyaltabb modell empirikus tesztelésére is szükség lesz.

\section{Lábjegyzet}

${ }^{1}$ Köszönöm a lektor hasznos megjegyzéseit és alapos munkáját.

\section{Felhasznált irodalom}

Andersen, P.H. - Kumar, R. (2006): Emotions, Trust and Relationship Development in Business Relationship: A Conceptual Model for Buyer-Seller Dyads. Industrial Marketing Management, Vol. 35, No. 4, p. 522-535.

Bolton, R.N. - Drew, J.H. (1991): A Multistage Model of Customer' Assessments of Service Quality, and Value. Journal of Consumer Research, january, p. 375-384.

Chang, T.Z. - Wildt, A.R. (1994): Price, Product Information and Purchase Intention. An Empirical Study. Journal of Marketing Science, n. 1. p. 16-27.

Costabile, M. (2000): A dynamic model of customer loyalty. IMP Conference, Bath, U.K.

Dick, A.S. - Basu, K. (1994): Customer Loyalty: Toward an Integrated Conceptual Framework. Journal of the Academy of Marketing Science, Winter, p. 99-113.

Dickey, J.D. (1998): Creating a customer satisfaction measurement system. Industrial Management, Mar/Apr. Vol. 40, Issue 2.

Edvardsson, B. - Johnson, M.D. - Gustafsson, A. - Stranvik, T. (2000): The effects of satisfaction and loyalty on profits and growth: products versus services. Total Quality Management, Vol. 11. No. 7, p. 917-927.

Elliot, G. - Glynn, W. (2000): Segmenting Industrial Buyers by Loyalty and Value. IMP Conference, Bath, U.K.

Ercsey I. (2008): A közüzemi szolgáltatások fogyasztói megítélése avagy elégedettség garantálva. PhD-tézisek, SZIE, Győr

Fredericks, J.O. - Salter J.M. (1995): Beyond customer satisfaction. Management Review, May/Vol. 84. Issue 5.

Gedeon, I.M. - Fearne, A.- Poole, N. (2009): The role of inter-personal relationships in the dissolution of business relationships. The Journal of Business \& Industrial Marketing, p. 218-226. 
Geyskens, I. - Steenkamp, J.B. (1995): An Investigation into the Joint Effects of Trust and Interdependence on Relationship Commitment. EMAC Conference Proceedings, Paris, Group ESSEC, p. 351-371.

Gitomer, J. (1998): The value of loyalty can't be measured. South Florida Business Journal, 08/21. Vol. 19, Issue, 1.

Grönholdt, L. - Martensen, A. - Kristensen, K. (2000): The relationship between customer satisfaction and loyalty: cross-industry differences. Total Quality Management, Vol. 11, No., 4/5\&6, p. 509-514.

Hetesi E. (2007): A lojalitás klaszterei a partneri és a fogyasztói piacokon. Vezetéstudomány, 9. sz. p. 4-17.

Hetesi, E. (2001): A marketingmunka dolgozói megítélésének, valamint a lakossági fogyasztói lojalitás mérése és elemzése a hazai közüzemi szolgáltatások körében. PhD-disszertáció, PTE

Hetesi E. - Vilmányi M. (2009): Modellezhető-e az üzleti kapcsolatok teljesítményének értelmezése? Szakirodalmi összefoglalás és modellfejlesztés. Vezetéstudomány, XXXX. évf. 1. sz. p. 34-44.

Hofmeister-Tóth Á. - Simon, J. - Sajtos, L. (2003): Fogyasztói elégedettség. Alinea Kiadó, Budapest

Jakoby, J. - Chestnut, R.W. (1978): Brand Loyalty. Measurement and Management, John Wiley \& Sons, New York

Meugniot, J. (2008): B2B Loyalty: Better Service Means Loyal Clients, Guidance, Thursday, May 22, http:// meugniot.blogspot.com/

Jones, T. O. - Sasser, Jr. W.E. (1995): Why satisfied customer defect? Harvard Business Review, Nov/Dec, Vol. 73, Issue 6.

Kandampully, J. (1998): Service quality to service loyalty: A relationship which goes beyond customer services. Total Quality Management, Aug. Vol. 9, Issue 6, p. 431-444.

Keaveney, S.M. (1995): Customer switching behavior in service industries: an exploratory study. Journal of Marketing, 59, p. 71-82.

Kenesei, Zs. (1998): Vertikális kapcsolatok elemzése és mérése a kereskedelmi bankok tevékenységében. $\mathrm{PhD}$ disszertáció, BKE, Budapest

Martensen, A. - Grönholdt, L. - Kristensen, K. (2000): The drivers of customer satisfaction and loyalty: cross industry findings from Denmark. Total Quality Management, Vol. 11, Nos, 4/5\&6, p. 544-553.

Meyer, J.P. - Allen, N. J. (1991): A Three-Component Conceptualization of Organizational Commitment. Human Recource Management Review, 1, p. 61-89.
Morgan, R.M. - Hunt, S.D. (1994): The Commitment-Trust Theory of Relationship Marketing. Journal of Marketing, 58. Jul/ 20-38. p n. 63, p. 384-399.

Neal, W.D. (1999): Satisfaction is Nice, But Value Drivers Loyalty. Marketing Research, Spring, Vol. 11., Issue 1.

Newman, J.W. -Werbel, R.A. (1973): Multivariate Analysis of Brand Loyalty for Major Household Appliances. Journal of Marketing Research, 10. Nov, p. 404-409.

Oliver, R.L. (1997): Satisfaction: A Behavioral Perspective on the Consumer. Irwin/McGraw - Hill, New York

Oliver, R.L. (1999): Whence Consumer Loyalty? Journal of Marketing. Vol. 63, (Special Issue) p. 33-44.

Parasuraman, A. - Grewal, D. (2000): The Impact of Technology on the Quality-Value-Loyalty Chain: A Research Agenda. Journal of the Academy of Marketing Science. V. 28, No.1, p.168-174.

Pritzhard, M.P. - Havitz, M.E. - Howard, D.R. (1999): Analyzing the Commitment-Loyalty Lonk in Service Contexts. Journal of the Academy of Marketing Science, Vol. 27, Issue 3, p. 333.

Reicheld, F.F. - Sasser, W.E. (1990): Zero Defections: Quality Comes to Services. Harvard Business Review, 8. Sept/Okt

Reicheld, F.F. (1996): The Loyalty Effect. Harvard Business School Press. Boston MA.

Reid, D.A. - Bolman-Pullins, E. - Plank, R.E. - Buehrer, R.E. (2004): Measuring Buyers' Perceptions of Conflict in Business-to-Business Sales Interactions. Journal of Business \& Industrial Marketing, Vol. 19, No. 4, p. 236-249.

Tellis, G.J. (1988): Advertising Exposure, Loyalty and Brand Purchase: A Two - Stage Model of Choice. Journal of Marketing Research, 25. May, p. 134-144.

Tuckman B.W. (1965): Developmental sequence in small groups. Psychological Bullettin

Veres, Z. (2007): „A kockázat megmarad, csak az érzet változik" - Tranzakciós és kapcsolati preferenciák a projekttípusú üzleti szolgáltatások piacán, Vezetéstudomány, XXXVIII. évf., 9. sz., p. 51-64.

Veres Z. (2008): Egy régi mánia: A gap-modell az elégedettségkutatásban. Marketing \& Menedzsment, XLII. évf., 2. sz., p. 4-17.

Wernerfelt, B. (1991): Brand Loyalty and Market Equilibrium. Market Science, Summer, p. 119-245.

Wind, Y. (1997): Brand Loyalty and Vulnerabilty, in: Woodside, A.G.- Sheth, J.N. - Benneth, P.D. (ed.): Consumer and Industrial Buying Behavior, North Holland, New York 